\title{
UJI DAYA HAMBAT EKSTRAK ETANOL DAUN JERANGAU HIJAU TERHADAP Staphylococcus aureus
}

\section{The Inhibitory Test of Ethanolic Extract of Jerangau Hijau Leaves against Staphylococcus aureus}

\author{
*Susi Novaryatiin, Guntur Satrio Pratomo, \& Cindia Yunari \\ Department of Pharmacy, Faculty of Health Science, Universitas Muhammadiyah Palangkaraya, RTA. Milono St. Km. I.5 Palangka Raya, \\ Indonesia \\ *e-mail : susi_novaryatiin@yahoo.com
}

\begin{abstract}
ABSTRAK
Jerangau Hijau merupakan tumbuhan obat yang dipercaya oleh masyarakat di Kalimantan Tengah memiliki khasiat untuk mengobati demam, luka pasca melahirkan, dan sebagai antiradang. Berdasarkan penelitian sebelumnya, Jerangau Hijau diketahui memiliki kandungan senyawa kimia yaitu flavonoid dan saponin yang memiliki aktivitas sebagai antibakteri. Tujuan penelitian ini untuk mengetahui mengetahui apakah ekstrak etanol daun Jerangau Hijau mampu menghambat pertumbuhan bakteri Staphylococcus aureus, serta untuk mengetahui konsentrasi ekstrak etanol daun Jerangau Hijau yang mampu menghambat pertumbuhan bakteri Staphylococcus aureus. Penelitian ini dilakukan menggunakan metode Kirby-Bauer dengan kertas cakram (disc). Proses ekstraksi dilakukan dengan metode perkolasi menggunakan pelarut etanol 96\%. Hasil penelitian menunjukkan bahwa ekstrak etanol daun Jerangau Hijau mampu menghambat pertumbuhan bakteri


$26,5 \pm 3,8 \mathrm{~mm}$; dan $13,1 \pm 3 \mathrm{~mm}$.
\end{abstract}

Kata kunci: Uji daya hambat, Jerangau Hijau, Staphylococcus aureus

\begin{abstract}
Jerangau Hijau is a medicinal plant believed by the people of Central Kalimantan to have efficacy of treating fever, postpartum injuries and antiinflammatory. Based on previous research, Jerangau Hijau is known to contain chemical compounds namely flavonoids and saponins that have activity as an antibacterial. The purpose of this study was to find out whether the ethanolic extract of Jerangau Hijau leaves able to inhibit the growth of Staphylococcus aureus bacteria, and to know the concentration of ethanolic extract of Jerangau Hijau leaves that able to inhibit the growth of Staphylococcus aureus bacteria. This research was conducted using Kirby-Bauer method with disc paper. The extraction process was carried out by percolation method using $96 \%$ ethanol solvent. The results showed that the ethanolic extract of Jerangau Hijau leaves was able to inhibit the growth of Staphylococcus aureus bacteria, at concentrations of $1 \%, 5 \%, 10 \%$, and 15\% with mean inhibitory zones respectively $22 \pm 0,2 \mathrm{~mm} ; 32,3 \pm 1,4 \mathrm{~mm}$; $26,5 \pm 3,8 \mathrm{~mm}$; and $13,1 \pm 3 \mathrm{~mm}$.
\end{abstract}

Keywords: The inhibitory test, Jerangau Hijau, Staphylococcus aureus

\section{PENDAHULUAN}

Indonesia merupakan salah satu negara yang memiliki hutan hujan tropis terbesar di dunia. Hutan hujan tropis yang sangat luas dengan kekayaan keanekaragaman hayati di dalamnya merupakan sumber daya alam dan gudang tumbuhan obat, sehingga dunia menjuluki Indonesia sebagai live laboratory (Wijayakusuma, 2007). Hal tersebut karena Indonesia memiliki 30.000 spesies tumbuhan, dari jumlah tersebut sekitar 9.600 spesies diketahui berkhasiat obat, dan baru 200 spesies yang telah dimanfaatkan sebagai bahan baku pada industri obat tradisional (Hapsoh \& Hasanah, 20II).

Kalimantan merupakan pulau di Indonesia yang terkenal dengan kekayaan keanekaragaman hayatinya. Tak hanya itu, kekayaan pengetahuan pengobatan tradisional dengan menggunakan tumbuhan yang diwariskan secara lisan dari generasi ke generasi pada etnis asli di Kalimantan juga sangat banyak. Potensi tumbuhan obat di hutan Kalimantan adalah terbesar di berbagai kawasan hutan dengan tingkat keanekaragamaan yang tinggi, beragam habitus, dan bagian yang digunakan (Norhidayah \& Sidiyasa, 2005).

Pengobatan tradisional yang bahannya dari sumber daya alam hayati seperti tumbuh-tumbuhan telah lama digunakan oleh masyarakat Indonesia. Hingga kini jamu tradisional masih digunakan oleh sebagian besar masyarakat untuk mengobati berbagai penyakit. Tumbuhan obat merupakan salah satu topik yang sangat penting dalam obat tradisional dan sebagai bahan alternatif untuk menyembuhkan berbagai penyakit (Arifin, 2009).

Tumbuhan Jerangau Hijau merupakan tumbuhan yang memiliki khasiat sebagai obat tradisional, di Kalimantan Tengah khususnya di Desa Mentaren II Kabupaten Pulang 
Pisau, daun Jerangau Hijau dipercaya oleh masyarakat setempat memiliki khasiat secara empiris sebagai tumbuhan obat untuk mengobati penyakit demam, antiradang dan luka pasca melahirkan. Penggunaan daun Jerangau Hijau yaitu dengan cara ditumbuk kemudian disaring dan airnya diminum (Anisah et al., 2014).

Kandungan kimia yang terdapat pada daun Jerangau adalah flavonoid dan saponin sedangkan rimpangnya mengandung tanin, protein, kalsium oksalat dan minyak atsiri (Wahyuni et al., 2012). Pada penelitian yang dilakukan oleh Anisah et al. (20/4) menjelaskan bahwa ekstrak etanol dan air rimpang Jerangau yang diperoleh di kabupaten Pontianak mampu menghambat pertumbuhan bakteri Escherichia coli dan Staphylococcus aureus. Berdasarkan penelitian yang dilakukan oleh Nuraini (2017) mengenai Standarisasi Simplisia Daun Jerangau Hijau asal Desa Mentaren II Kabupaten Pulang Pisau, kandungan kimia/zat aktif pada simplisia daun Jerangau Hijau yaitu flavonoid dan saponin, yang diketahui memiliki aktivitas biologi dan salah satunya sebagai antibakteri.

Staphylococcus aureus merupakan salah satu bakteri Gram positif berbentuk bulat. Bakteri ini merupakan bakteri patogen utama pada manusia yang menyebabkan berbagai penyakit secara luas (Putra et al., 2017). Staphylococcus aureus dikenal sebagai bakteri yang paling sering mengkontaminasi luka pasca bedah sehingga menimbulkan komplikasi. Bila terjadi bakteriemia, infeksi dapat bermetastasis ke berbagai organ (DeLeo et al., 2009).

Peningkatan resistensi bakteri terhadap antibiotik mendorong adanya upaya untuk mendapatkan senyawa antibakteri dengan memanfaatkan senyawa bioaktif dari kekayaan keanekaragaman hayati. Oleh karena itu berdasarkan kandungan dan manfaat daun Jerangau Hijau tersebut peneliti tertarik untuk menguji daya hambat ekstrak etanol daun Jerangau Hijau terhadap pertumbuhan bakteri Staphylococcus aureus.

Penelitian ini bertujuan untuk mengetahui apakah ekstrak etanol daun Jerangau Hijau mampu menghambat pertumbuhan bakteri Staphylococcus aureus, serta untuk mengetahui konsentrasi ekstrak yang mampu menghambat pertumbuhan bakteri Staphylococcus aureus.

\section{METODOLOGI}

\section{Alat dan Bahan}

Alat-alat yang digunakan dalam penelitian ini adalah perkolator, rotary evaporator, Laminar Air Flow, autoklaf, dan inkubator.
Bahan-bahan yang digunakan pada penelitian ini yaitu ekstrak etanol daun Jerangau Hijau, bakteri Staphylococcus aureus ATCC 25923, disc kosong, antibiotik klindamisin, Standar McFarland 0,5 media Brain Heart Infusion (BHI), media Blood Agar Plate (BAP), media Mueller Hinton Agar (MHA), etanol $96 \%$, aquadest, $\mathrm{NaCl} 0,9 \% \mathrm{H}_{2} \mathrm{SO}_{4} 1 \%$ dan $\mathrm{BaCl}_{2} \mid \%$.

\section{Metode Penelitian}

I. Sampel Penelitian

Sampel penelitian adalah tumbuhan Jerangau Hijau yang tumbuh di Desa Mentaren II Kabupaten Pulang Pisau. Tumbuhan Jerangau Hijau yang diteliti adalah bagian daun yang segar.

2. Pembuatan Simplisia

Dilakukan sortasi basah pada daun Jerangau Hijau, lalu daun dipotong-potong, dan dijemur. Setelah kering simplisia disortasi kembali dan dihaluskan hingga menjadi serbuk (Materia Medika Indonesia, 1995).

3. Pembuatan Ekstrak

Pembuatan ekstrak daun Jerangau Hijau dilakukan dengan metode perkolasi. Keuntungan dari metode ini yaitu mudah, sederhana, dan peluang resiko pengotor sangat kecil karena digunakan pelarut yang selalu baru (exhaustive extraction) pada temperatur ruangan. Penggunaan pelarut etanol $96 \%$ karena etanol merupakan pelarut universal yang mampu melarutkan hampir seluruh jenis metabolit sekunder yang mempunyai berat molekul rendah seperti flavonoid, saponin, dan alkohol; tidak bersifat racun serta aman untuk digunakan (Arifianti et.al., 20l4). Dilakukan penimbangan ekstrak kental yang didapat. Ekstrak yang diperoleh lalu dibuat dalam berbagai variasi konsentrasi yaitu $1 \%, 5 \%$, $10 \%$, dan $15 \%$.

4. Penanaman Bakteri

Bakteri Staphylococcus aureus ditanam pada media BHI pada suhu $37^{\circ} \mathrm{C}$ selama 24 jam, lalu ditumbuhkan pada media BAP pada suhu $37^{\circ} \mathrm{C}$ selama 24 jam.

5. Uji Daya Hambat

Uji daya hambat dilakukan menggunakan metode difusi (Kirby-Bauer), dimana disc direndam dalam variasi konsentrasi ekstrak etanol daun Jerangau $\mathrm{Hijau} 1 \%, 5 \%$, 10\%, dan 15\%. Standar McFarland 0,5 disiapkan, dan 10 $\mathrm{ml}$ dimasukkan ke dalam tabung steril. Suspensi bakteri dibuat dengan mengambil koloni bakteri, diencerkan dalam $\mathrm{NaCl}$ steril, dan kekeruhan disesuaikan dengan standar McFarland 0,5. Suspensi bakteri diambil dan distreak pada media MHA dengan menggunakan lidi kapas 
steril. Kemudian semua disc yang telah direndam dalam ekstrak etanol daun Jerangau Hijau ditanam pada media MHA. Antibiotik klindamisin digunakan sebagai kontrol positif dengan variasi konsentrasi $1 \%$, 5\%, 10\%, dan 15\%. Disc yang telah direndam dalam klindamisin juga ditanam di media MHA. Inkubasi dilakukan pada suhu $37{ }^{\circ} \mathrm{C}$ selama 24 jam. Zona hambat diukur menggunakan jangka sorong. Dilakukan pengulangan sebanyak tiga kali untuk masing-masing ekstrak dan kontrol positif.

\section{Analisis Data}

Analisis data dilakukan dengan menghitung zona hambat ekstrak etanol daun Jerangau Hijau terhadap bakteri Staphylococcus aureus. Hasil disajikan dalam bentuk tabel disertai perbandingan antara hasil yang diperoleh dengan standar yang telah ditetapkan oleh CLSI (CLSI, 20I3).

\section{HASIL DAN PEMBAHASAN}

\section{Perhitungan Rendemen Ekstrak}

Rendemen $=$ Berat ekstrak kental $\times 100 \%$

$$
\begin{aligned}
& \text { Berat simplisia } \\
= & \frac{33,9062 \mathrm{gr} \times 100 \%}{300 \mathrm{gr}} \times 100 \%=11,30 \% \\
= & 0,1130 \times 100 \%
\end{aligned}
$$

Jumlah total ekstrak kental yang diperoleh adalah 33,9062 gr dan rendemen adalah I I,30\% (Gambar I).



Gambar I. Ekstrak Kental Daun Jerangau Hijau

\section{Uji Daya Hambat}

Hasil uji daya hambat ekstrak etanol daun Jerangau Hijau dapat dilihat pada Tabel I. Penelitian ini menggunakan kontrol positif yang berguna sebagai pembanding atau tolak ukur dalam menentukan kemampuan ekstrak dalam menghambat bakteri. Klindamisin mempunyai mekanisme membunuh bakteri dengan cara mencegah sintesis protein dari bakteri. Klindamisin merupakan antimikroba yang bersifat bakteriostatik maupun bakterisida (Putra et al.,
2017). Zona hambat yang dihasilkan oleh klindamisin pada konsentrasi 1\%, 5\%, 10\%, dan 15\% terhadap Staphylococcus aureus secara berturut-turut adalah 44,2 $\pm 1,3 \mathrm{~mm} ; 44,4 \pm 0,4$ mm; 48,3 $\pm 0,4$ mm; dan 48,7 I , I mm (Tabel I, Gambar 2). Berdasarkan CLSI, zona hambat klindamisin yang diujikan pada keempat konsentrasi tersebut dikategorikan susceptible.

Tabel I. Hasil Pengukuran Zona Hambat Ekstrak Etanol Daun Jerangau Hijau

\begin{tabular}{cccc}
\hline Uji & $\begin{array}{c}\text { Konsentrasi } \\
(\%)\end{array}$ & $\begin{array}{c}\text { Zona } \\
\text { Hambat } \\
\mathbf{\pm ~ S D} \\
(\mathbf{m m})\end{array}$ & $\begin{array}{c}\text { Interpretasi } \\
\text { Daya Hambat }\end{array}$ \\
\hline Kontrol & $\mathrm{I}$ & $44,2 \pm \mathrm{I}, 3$ & Susceptible \\
positif & 5 & $44,4 \pm 0,4$ & Susceptible \\
Clindamycin & 10 & $48,3 \pm 0.4$ & Susceptible \\
& 15 & $48,7 \pm 1,1$ & Susceptible \\
Ekstrak & 1 & $22,3 \pm 0,2$ & Susceptible \\
Etanol Daun & 5 & $32,3 \pm 1,4$ & Susceptible \\
Jerangau & 10 & $26,5 \pm 3,8$ & Susceptible \\
Hijau & 15 & $13,1 \pm 3$ & Resistant \\
\hline
\end{tabular}

Keterangan :

Interpretasi Daya Hambat (CLSI, 2013)

$\leq 14 \mathrm{~mm}=$ Resistant

$15-18 \mathrm{~mm}=$ Intermediate

$\geq 19 \mathrm{~mm}=$ Susceptible

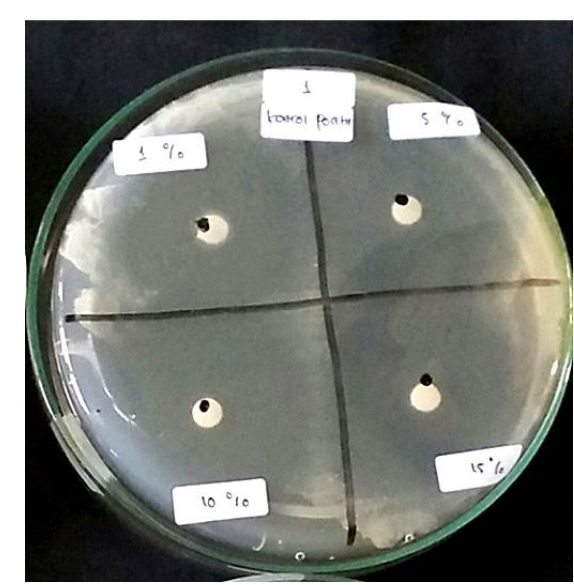

Gambar 2. Daya Hambat Tetrasiklin Terhadap Staphylococcus aureus

Uji daya hambat ekstrak etanol daun Jerangau Hijau dilakukan sebanyak 3 kali pengulangan, menunjukkan adanya zona hambat yang bervariasi (Gambar 3). Zona hambat pada konsentrasi $1 \%, 5 \%$, $10 \%$, dan $15 \%$ berturut-berturut sebesar 22,I $\pm 0,2 \mathrm{~mm} ; 32,3 \pm \mathrm{I}, 4 \mathrm{~mm} ; 26,5 \pm 3,8 \mathrm{~mm}$; dan I3, I $\pm 3 \mathrm{~mm}$ (Tabel I).

Jika dibandingkan dengan standar CLSI, maka zona hambat yang dihasilkan oleh ekstrak etanol daun Jerangau Hijau pada konsentrasi $1 \%$, 5\%, dan 10\% dapat dikategorikan susceptible sedangkan pada konsentrasi 15\% dikategorikan resistant. 


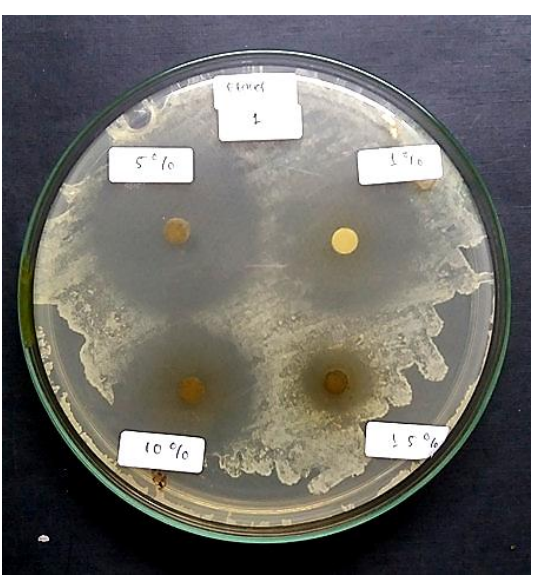

Gambar 3. Daya Hambat Ekstrak Etanol Daun Jerangau Hijau Terhadap Staphylococcus aureus

Hasil berupa zona bening yang terbentuk dikarenakan terdapat kandungan senyawa aktif pada daun Jerangau Hijau berupa flavonoid dan saponin yang berperan sebagai antibakteri sehingga dapat menghambat pertumbuhan bakteri (Nuraini, 2017). Flavonoid merupakan senyawa fenol yang bekerja dengan cara mendenaturasi protein yang dapat menyebabkan aktivitas metabolisme sel dikatalis oleh suatu enzim yang merupakan protein. Karena flavanoid memiliki kemampuan untuk membentuk kompleks dengan protein ekstraseluler terlarut dan dengan dinding sel, sehingga mikroorganisme tidak dapat melekat dan menginvasi sel (Susanti, 2016). Flavonoid juga mampu melepaskan energi tranduksi terhadap membran sitoplasma bakteri dan menghambat motilitas bakteri (Manik et al., 2016). Selain itu, flavonoid juga dapat menyebabkan kerusakan dinding sel bakteri melalui penghambatan yang mengakibatkan penggabungan rantai glikan tidak terhubung silang ke dalam peptidoglikan membran sel sehingga menjadi satu struktur yang lemah (Sulatstrianah et al., 2014).

Saponin bertindak sebagai penghalang kimia dalam sistem pertahanan tanaman menghadapi patogen. Saponin dapat menyebabkan kebocoran protein dan enzim tertentu sel bakteri (Ravi et al., 2016). Saponin merupakan senyawa yang berfungsi sebagai antibakteri, mempercepat pertumbuhan sel-sel baru, merangsang pembentukan fibroblast, menghambat pertumbuhan bakteri, dan juga bersifat antijamur (Yuliana et al., 2015). Mekanisme saponin sebagai antibakteri adalah dengan cara merusak membran sel bakteri akibat terjadinya peningkatan permeabilitas membran oleh karena saponin yang berinteraksi dengan dinding sel bakteri (Sulastrianah et al., 20I4).

\section{KESIMPULAN}

Berdasarkan hasil penelitian yang telah dilakukan, maka dapat disimpulkan bahwa ekstrak etanol daun Jerangau
Hijau mampu menghambat pertumbuhan bakteri Staphylococcus aureus, pada konsentrasi 1\%, 5\%, 10\%, dan $15 \%$ dengan rata-rata zona hambat berturut-turut $22 \pm 0,2$ $\mathrm{mm} ; 32,3 \pm \mathrm{I}, 4 \mathrm{~mm} ; 26,5 \pm 3,8 \mathrm{~mm}$; dan $13,1 \pm 3 \mathrm{~mm}$. Perlu dilakukan penelitian lanjutan dengan menggunakan ekstraksi cara panas seperti sokhletasi, untuk melihat perbandingan kemampuan daya hambat ekstrak daun Jerangau Hijau terhadap bakteri Staphylococcus aureus.

\section{DAFTAR PUSTAKA}

Anisah, Khotimah, S. dan Yanti, A.H. 20I4. Aktivitas antibakteri ekstrak rimpang jeringau (Acoros calamus L.) terhadap pertumbuhan Staphylococcus aureus dan Echerichia coli. Jurnal Protobiont. 3(3): I.

Arifianti, L., Oktarina, R.D. dan Kusumawati, I. 2014. Pengaruh jenis pelarut pengekstraksi terhadap kadar sinesetin dalam ekstrak daun Orthosiphon stamineus benth. E-Jurnal, 2(I):3.

Arifin, A.S. 2009. Tumbuhan Obat Indonesia. Bandung, Institut Teknologi Bandung.

Clinical Laboratory Standart Institute. 2013. Performance Standart for Antimicrobial Susceptibility Testing; Twentieth Information Supplement. USA.

DeLeo, F.R., Diep, B.A. dan Otto, M. 2009. Host defense and pathogenesis in Staphylococcus aureus infections. J Dent. 23(I):17-34.

Departemen Kesehatan Republik Indonesia. 1995. Materia Medika Indonesia Jilid VI. Jakarta, Departemen Kesehatan Republik Indonesia.

Hapsoh dan Hasanah. 20II. Budidaya Tanaman Obat dan Rempah. Medan, USU Press.

Manik, D.F., Hertiani, T., dan Anshory, H. 2014. Analisis kolerasi antara kadar flavanoid dengan aktivitas antibakteri ekstrak etanol dan fraksi-fraksi daun kersen (Muntingia calaburam L.) terhadap Staphylococcus aurues. Khazanah, 6(2): I-I I.

Nuraini, I. 2017. Standarisasi simplisia daun jerangau hijau (Acorus Calamus Linn.) asal Desa Mantaren II Kabupaten Pulang Pisau. Karya Tulis Ilmiah, Fakultas IImu Kesehatan, Universitas Muhammadiyah Palangkaraya.

Noorhidayah dan Sidiyasa. 2005. Keanekaragaman tumbuhan berkhasiat obat di Taman Nasional Kutai, Kalimantan Timur. Jurnal Analisis Kebijakan Kehutanan, 2(2): I I5-I 28.

Putra, R.E.D., Homenta, H. dan Wowor, V.N.S. 2017. Uji daya hambat perasan jeruk purut Citrus Hytrix terhadap bakteri Staphylocuccus aureus secara in vitro. Jurnal Ilmiah Farmasi. 6(I):65-66.

Ravi, L., Manasvi, V., dan Praveena, L.B. 2016. Antibacterial and antioxidant activity of saponin from 
Abutilon indicum leaves. Asian J Pharm Clin Res, 9:344347.

Sulastrianah., Imran, dan Fitria, E.S. 20I4. Uji daya hambat ekstrak daun sirsak (Annona muricata L) dan daun sirih (Piper betle L) terhadap pertumbuhan bakteri Escherichia coli. Jurnal UHO, I (I):76-84.

Susanti, N. 2016. Aktivitas antimikroba ekstrak rimpang jeringau terhadap pertumbuhan Candida albicans. Jurnal Biodjati, I(I):55-58.
Wahyuni, A., Kadir, A., dan Najib, A. 2012. Isolasi dan identifikasi komponen kimia fraksi N-heksana dalam tumbuhan jeringau (Acorus calamus Linn.). AsSyifaa, 4(I):58-64.

Wijayakusuma, M.H. 2007. Penyembuhan dengan Temulawak. Jakarta, Sarana Pustaka Prima.

Yuliana, S.R.I., Leman, M.A., dan Anindita, P.S. 20I5. Uji daya hambat senyawa saponin batang pisang (Musa paradisiacal) terhadap pertumbuhan Candida albicans. Jurnal e-GiGi, 3(2):2. 